Nippon Suisan Gakkaishi $\quad \mathbf{8 0}(1), 116(2014)$

\title{
ミニシンポジウム 志摩半島周辺海域における二枚貝類養殖の現状
}

\section{I-1． 伊勢湾口海域におけるマガキ種苗の 確保とその特性}

松本才絵

独水産総合研究センター 増養殖研究所

I-1. Production and characterization of the oyster seeds in Ise Bay

TOSHIE MATSUMOTO

National Research Institute of Aquaculture, Fisheries Research Agency, Minami-ise, Mie 516-0193, Japan

\section{1. 三重県のマガキ養殖}

マガキ養殖は三重県の重要な水産業の一つである。県 内では, 紀北町の渡利地区で天然採苗による地元産種苗 を用いて養殖しているほかは，大半が宮城県で生産され た種苗を用いている。2011年の東北地方太平洋沖地震 に伴う津波により, 県内のマガキ養殖場においても施設 の損傷等大きな被害が発生したが，さらに宮城県からの マガキ種苗の入手が困難になることが懸念された。宮城 県ではカキ養殖の復興のため種ガキの採苗に取り組み, 2011 年は例年の 4 割にあたる約 40 万連の種ガキが採 苗され, 県外にも出荷された。翌 2012 年の採苗は例年 の約 8 割まで回復している。 供給されるかは不明で，少しでも多くの種苗を確保する ため三重県水産研究所等と協力して, 県内の養殖海域で 天然採苗を行うための調査を実施した。

\section{2. 種苗確保に向けた取り組み}

マガキは海の中で産卵, 受精する。受精後, 幼生とな り $2 \sim 3$ 週間の浮遊幼生期を経て, 殼長が $0.3 \mathrm{~mm}$ 前後 になると物に付着する。このとき採苗器を海に入れて, カキの種苗をとることができる。天然採苗により種苗を 得ている宮城県では, 水温などの海況とカキの産卵状 況, 浮遊幼生の出現状況, 採苗器への付着状況を調査し て抢り, 同様の調査を三重県の主要なマガキ生産海域で ある伊勢湾口域でも行った。

2011 年 5 月 9 月に週 1 2 回の頻度で鳥羽, 浦村及 び的矢海域において，水温や塩分などの観測と合わせて 幼生採集を実施し，幼生の出現状況に合わせて付着数を 観測する種見調查を行った。2012 年は鳥羽及び浦村海 域で同様の調查を行った。両年とも, 幼生の出現ピーク が複数回見られたが，幼生の密度は 2011 年に比べ 2012 年は低かった。付着数は, 2011 年にはいずれの海 域でも少なくとも 1 回はピークが見られた。2012 年 は, 鳥羽海域では幼生密度は低かったが付着数は前年と
同程度であり, 浦村海域では前年より少なかった。この ため 2012 年はやや低調であったが, 両年とも天然採苗 により種苗を得ることができた。2

天然採苗による種苗は確保できたものの, さらに安定 して効率的に採苗するためには課題もある。的矢海域で は浦村海域よりも幼生の出現数も稚貝の付着数も多く, 順調に採苗できた。しかしこの海域ではフジッボの付着 も多く, 成育の過程で採苗器がフジッボに覆われた。浦 村海域では流速計を設置し流動調査を行った結果, 海水 が比較的短期間に交換し, また湾内から湾外へ流出する 傾向にあった。このため湾内の幼生の大半は湾外へ流出 してしまい, 幼生密度も低く稚貝の付着数も少なかった と考えられた。このような海域では, 幼生数や付着数の 多い宮城県での方法とは異なる採苗方法を開発すること が必要である。

\section{3. 種苗の特性調査}

天然種苗は 2011 年に浦村海域と的矢海域で, 2012 年には浦村海域で採苗し, 人工種苗は 2011, 2012 年に 三重県水産研究所に扔いて宮城県産マガキを親貝にして 得た。これら三重県産の天然種苗と人工種苗が，これま で養殖されてきた宮城県産種苗と比較してどういう特性 を持つのかを明らかにするため, 飼育試験を行った。 2011 年に採苗された三重県産の天然種苗と人工種苗及 び宮城県産種苗を，2011年 11 月から 2013 年 1 月まで 鳥羽, 浦村及び的矢海域で垂下飼育し, 飼育期間中の成 育状況と飼育終了時には軟体部の状態について調查し た。飼育期間中，いずれの海域においても殼の成長や形 態 (殼高/殼長) に種苗による差異は認められなかった。 飼育終了時には殼の成長や形態, 軟体部重量, 軟体部の 組織観察, グリコーゲン量について調査したが，いずれ の海域においても種苗による一定の傾向, 差異は認㕫 れなかった。これらのことから三重県で採苗された種苗 は宮城種苗と同様の成育特性を有すると評価され, 三重 県産マガキ種苗は養殖現場に導入できる可能性が示され た (青木等, 未発表)。現在は2012年産の種苗の特性調 査が進行中であり, 三重県産種苗の利用に向けて知見を さらに集積することが必要である。

\section{文献}

1）田邊 徹. マガキCrassostrea gigas 養殖に対する東日本大 震災の影響と復興への取組. 日水誌 2013; 79: 721-723.

2) 舘 洋, 畑 直亜, 斉藤洋一, 岩尾豊紀. 鳥羽志摩海域 におけるマガキの天然採苗の試み. 三重水研報 2013; 22: 17-24. 